\title{
EVALUASI KESESUAIAN OBAT DAN DOSIS ANTIHIPERTENSI DI INSTALASI RAWAT JALAN RUMAH SAKIT " $X$ " KOTA TASIKMALAYA
}

\section{EVALUATION OF THE SUITABILITY OF ANTIHYPERTENSIVE DRUGS AND DOSE IN OUTPATIENTS AT HOSPITAL " $X$ " TASIKMALAYA}

\author{
Nida Ahadiah ${ }^{1 *}$, H. Eddy Suhardiana ${ }^{2}$, Nuri Handayani ${ }^{3}$ \\ ${ }_{1,2}$ Fakultas IImu Kesehatan Universitas Perjuangan, Indonesia \\ ${ }^{3} J$ urusan Farmasi Poltekkes Kemenkes Tasikmalaya, Indonesia \\ *) Email :'nidaahadiah22@gmail.com, ${ }^{2}$ eddysuhardiana@gmail.com, ${ }^{3}$ nurihandayani882@gmail.com
}

\begin{abstract}
ABSTRAK
Hipertensi merupakan salah satu penyebab utama mortalitas dan morbiditas di Indonesia. Prevalensi hipertensi akan terus meningkat tajam, sehingga penggunaan obat yang rasional oleh pasien hipertensi perlu diperhatikan karena merupakan salah satu elemen penting dalam tercapainya kualitas kesehatan. Dalam pengobatannya, terapi penggunaan obat antihipertensi perlu dievaluasi untuk meningkatkan keberhasilan terapi. Tujuan penelitian untuk mengetahui evaluasi kesesuaian obat dan dosis antihipertensi di instalasi rawat jalan RS " $X$ " Kota Tasikmalaya. Penelitian ini merupakan penelitian observasional deskriptif evaluatif dengan pengumpulan data secara prospektif dan teknik pengambilan sampel secara purposive sampling. Data pasien dan profil penggunaan obat antihipertensi diperoleh melalui catatan medik pasien. Diperoleh sampel yang memenuhi kriteria inklusi sebanyak 100 sampel. Semua data sampel kemudian diolah dan dianalisis untuk mengetahui kesesuaian obat dan dosis antihipertensi kemudian disesuaikan dengan rekomendasi dari JNC VIII. Hasil penelitian menunjukkan gambaran terapi antihipertensi terbanyak di instalasi rawat jalan RS "X" pada bulan Juni-Juli 2019 adalah amlodipine untuk terapi tunggal dan untuk terapi kombinasi adalah amlodipine dengan lisinopril. Pada evaluasi kesesuaian obat dan dosis antihipertensi terdapat ketidaksesuaian penggunaan obat yaitu, 5 kasus pada pasien hipertensi dengan DM sebesar 4,8\%, 4 kasus pada pasien hipertensi dengan CKD sebesar $80 \%$ serta 2 kasus ketidaksesuaian dosis berupa dosis yang kurang dari dosis yang dianjurkan yaitu pada penggunaan obat lisinopril sebesar 1,3\%.
\end{abstract}

Kata kunci: hipertensi, kesesuaian obat dan dosis, obat antihipertensi

\begin{abstract}
Hypertension is one of the main causes of mortality and morbidity in Indonesia. So that in treatment, the use of antihypertensive drugs needs to be evaluated to increase the success of therapy. This research was determine the characteristics of hypertensive patients, an overview of antihypertensive therapy and to determine the evaluation of drug suitability and antihypertensive doses in outpatients at " $X$ " Hospital in Tasikmalaya. This research is an evaluative observational descriptive study with prospective data collection and purposive sampling technique. Patient data and profiles of antihypertensive drug use were obtained through patient medical records. Obtained samples that met the inclusion criteria of 100 samples. All data obtained then processed and
\end{abstract}


analyzed to determine the suitability of the drug and antihypertensive dose and adjusted to the recommendations of JNC VIII. Result shows the most use of antihypertensive drugs in outpatients in "X" Hospital in June-July 2019 is amlodipine for monotherapy and for combination therapy is amlodipine with lisinopril. In evaluating the suitability of the drug and antihypertensive dose there is a discrepancy in the use of the drug that is, 5 cases in patients with hypertension with DM of $4.8 \%$, 4 cases in hypertensive patients with CKD of $80 \%$ and 2 cases of dose mismatch in the form of doses that are less than the recommended dose ie in the use of the drug lisinopril by $1.3 \%$.

Keywords: antihypertensive drugs, drug suitability and dosage, hypertension

\section{PENDAHULUAN}

Hipertensi merupakan salah satu penyebab utama mortalitas-morbiditas di Indonesia sehingga tatalaksana penyakit ini merupakan intervensi yang sangat umum dilakukan di berbagai tingkat fasilitas kesehatan ${ }^{14}$. Pada kebanyakan kasus, hipertensi terdeteksi saat pemeriksaan fisik karena alasan penyakit tertentu, sehingga sering disebut sebagai "silent killer". Tanpa disadari penderita mengalami komplikasi pada organ-organ vital seperti jantung, otak ataupun ginjal ${ }^{4}$.

Data dari World Health Organization (WHO) tahun 2014, satu milyar orang di dunia menderita hipertensi, 2/3 diantaranya berada di negara berkembang yang berpenghasilan rendah sampai dengan sedang. Prevalensi hipertensi akan terus meningkat tajam, diprediksi pada tahun 2025 sebanyak 29\% orang dewasa di seluruh dunia terkena hipertensi. Hipertensi telah mengakibatkan kematian sekitar 8 juta orang setiap tahun, 1,5 juta kematian terjadi di Asia Tenggara. Namun, hampir sekitar 90-95\% kasus tidak diketahui penyebabnya. Data tahun 2007-2010 menunjukkan bahwa sebanyak $81,5 \%$ penderita hipertensi menyadari bahwa mereka menderita hipertensi, $74,9 \%$ menerima pengobatan dengan $52,5 \%$ pasien yang tekanan darahnya terkontrol (tekanan darah sistolik $<140 \mathrm{mmHg}$ dan diastolik $<90 \mathrm{mmHg}$ ) dan $47,5 \%$ pasien yang tekanan darahnya tidak terkontrol ${ }^{8}$.

Seiring dengan peningkatan kasus hipertensi maka penggunaan obat yang rasional oleh pasien hipertensi merupakan salah satu elemen penting dalam tercapainya kualitas kesehatan. Penggunaan obat yang rasional adalah ketika pasien menerima pengobatan sesuai dengan kebutuhan klinisnya, dalam dosis dan jangka waktu yang sesuai, serta dengan biaya terendah ${ }^{21}$.

Tujuan dari penggunaan obat rasional ini adalah untuk menghindari terjadinya DRPs (Drug Related Problems), dimana DRPs ini merupakan kejadian yang tidak diinginkan pasien terkait terapi obat, dan secara nyata maupun potensial berpengaruh pada outcome yang diinginkan pada pasien. Salah satu DRPs yang perlu diperhatikan adalah dosis obat. Jika dosis obat terlalu rendah, maka tujuan terapi tidak akan tercapai, sebaliknya jika dosis obat terlalu tinggi, maka konsentrasi obat dalam serum pasien di atas range terapeutik yang diharapkan ${ }^{2}$. Selain itu, dalam melakukan upaya terapi, kesesuaian obat harus dipilih berdasarkan diagnosa yang telah ditetapkan sehingga obat yang digunakan memiliki efek terapi sesuai dengan kategori penyakitnya ${ }^{7}$.

Evaluasi penggunaan obat antihipertensi bertujuan untuk memastikan penggunaan obat yang rasional kepada penderita hipertensi. Dimana penggunaan obat yang rasional sangat penting untuk meningkatkan keberhasilan terapi. Apabila penderita hipertensi tidak diterapi, dapat menyebabkan terjadinya komplikasi yang dapat memperburuk keadaan penderita ${ }^{19}$.

Berdasarkan hal tersebut, mendorong peneliti untuk melakukan penelitian terhadap kerasionalan penggunaan obat antihipertensi dengan memfokuskan pada kesesuaian obat 
dan dosis antihipertensi. Penelitian ini dilakukan pada pasien rawat jalan tepatnya di Poliklinik Penyakit Dalam Rumah Sakit " $X$ " Kota Tasikmalaya.

\section{METODE}

Penelitian ini merupakan penelitian observasional deskriptif evaluatif dengan metode pengambilan data secara prospektif dengan desain penelitian yang digunakan adalah cross sectional, yaitu observasi atau pengukuran yang dilakukan terhadap variabel bebas dan variabel terikat yang dilakukan sekali dalam waktu yang bersamaan, sehingga akan mendapatkan gambaran hasil evaluasi kesesuaian obat dan dosis antihipertensi pada pasien rawat jalan Poliklinik Penyakit Dalam RS "X" Tasikmalaya.

Populasi pada penelitian ini adalah seluruh pasien rawat jalan poliklinik penyakit dalam yang didiagnosis hipertensi di RS "X" Tasikmalaya. Sampel penelitian ini adalah semua subjek yang ada dan memenuhi kriteria inklusi. Penentuan jenis sampel menggunakan teknik purposive sampling, yaitu suatu metode penarikan sampel probabilitas yang dilakukan dengan kriteria tertentu ${ }^{8}$. Sampel diambil berdasarkan kriteria inklusi. Adapun kriteria inklusi dalam penelitian ini adalah pasien rawat jalan poli dalam di RS "X" yang didiagnosis hipertensi pada bulan Juni sampai Juli 2019, berusia > 18 tahun, memiliki identitas lengkap yang tercatat dalam catatan medik pasien, tanpa penyakit penyerta maupun dengan penyakit penyerta diabetes melitus (DM) atau dengan penyakit ginjal (Chronic Kidney Disease). Sedangkan kriteria eksklusi dalam penelitian ini adalah pasien ibu hamil, catatan medik yang tidak lengkap dan tidak terbaca. Data yang diambil dibuat dalam tabulasi lembar kerja pengumpulan data yang meliputi nama pasien, usia, jenis kelamin, tekanan darah, serta terapi pengobatan.

Analisis data yang akan digunakan dalam penelitian ini yaitu secara deskriptif. Statistik deskriptif adalah statistik yang digunakan untuk menganalisis data dengan cara mendeskripsikan atau menggambarkan data yang telah terkumpul sebagaimana adanya tanpa bermaksud membuat kesimpulan yang berlaku untuk umum atau generalisasi ${ }^{1}$. Data pada penelitian ini berupa data penggunaan obat antihipertensi, yang kemudian dianalisis untuk menjelaskan persentase kesesuaian obat dan dosis antihipertensi yang diterima oleh pasien hipertensi.

\section{HASIL}

Tabel 1. Karakteristik pasien hipertensi berdasarkan jenis kelamin

\begin{tabular}{ccc}
\hline Jenis Kelamin & Frekuensi & Persentase \\
\hline Laki-laki & 25 & $25 \%$ \\
Perempuan & 75 & $75 \%$ \\
\hline Jumlah & 100 & $100 \%$ \\
\hline
\end{tabular}

Tabel 2. Karakteristik Pasien Hipertensi berdasarkan Usia

\begin{tabular}{ccc}
\hline Usia & Frekuensi & Persentase \\
\hline Dewasa awal (26-35 thn) & 1 & $1 \%$ \\
Dewasa akhir (36-45 thn) & 11 & $11 \%$ \\
Lansia awal (46-55 thn) & 31 & $31 \%$ \\
Lansia akhir (56-65 thn) & 39 & $39 \%$ \\
Manula ( > 65 thn) & 18 & $18 \%$ \\
\hline \multicolumn{1}{c}{ Jumlah } & 100 & $100 \%$ \\
\hline
\end{tabular}

Tabel 3. Karakteristik Pasien berdasarkan Kategori Hipertensi menurut JNC VIII

\begin{tabular}{lcc}
\hline \multicolumn{1}{c}{ Kategori Hipertensi } & Frekuensi & Persentase \\
\hline Hipertensi Tunggal & 3 & \\
$<60$ thn & 9 & $3 \%$ \\
$\geq 60$ thn & 83 & $9 \%$ \\
Hipertensi dengan DM & 5 & $5 \%$ \\
Hipertensi dengan CKD & 100 & $100 \%$ \\
\hline \multicolumn{2}{c}{ Jumlah } &
\end{tabular}

Tabel 4. Penggunaan Terapi Antihipertensi

\begin{tabular}{ccc}
\hline Jenis Terapi & Frekuensi & Persentase \\
\hline Tunggal & 56 & $56 \%$ \\
Kombinasi & 44 & $44 \%$ \\
\hline Jumlah & 100 & $100 \%$ \\
\hline
\end{tabular}


Tabel 5. Gambaran Terapi pada Pasien dengan diagnosa Hipertensi Tunggal

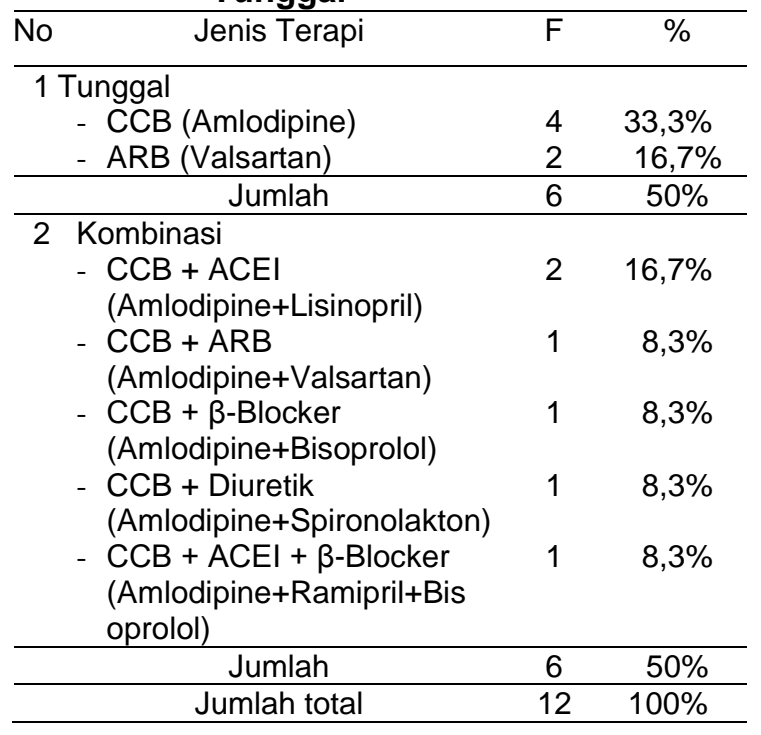

Tabel 6. Gambaran Terapi pada Pasien Hipertensi dengan DM

\begin{tabular}{|c|c|c|}
\hline Jenis Terapi & $\mathrm{F}$ & $\%$ \\
\hline \multicolumn{3}{|l|}{1 Tunggal } \\
\hline - CCB (Amlodipine) & 36 & $43,4 \%$ \\
\hline \multicolumn{2}{|l|}{ - ARB } & $6 \%$ \\
\hline - Valsartan & 7 & $8,4 \%$ \\
\hline - Candesartan & 1 & $1,2 \%$ \\
\hline - Telmisartan & 1 & $1,2 \%$ \\
\hline Jumlah & 50 & $60,2 \%$ \\
\hline \multicolumn{3}{|l|}{2 Kombinasi } \\
\hline \multicolumn{3}{|l|}{ - $\mathrm{CCB}+\mathrm{ACEI}$} \\
\hline (Amlodipine+Lisinopril) & 14 & $16,9 \%$ \\
\hline (Amlodipine+Ramipril) & 7 & $8,4 \%$ \\
\hline $\begin{array}{l}\text { - CCB + Diuretik } \\
\text { (Amlodipine+Spironolakton) }\end{array}$ & 3 & $3,6 \%$ \\
\hline $\begin{array}{l}\text { - ARB + } \beta \text {-Blocker } \\
\text { (Telmisartan+Bisoprolol) }\end{array}$ & 2 & $2,4 \%$ \\
\hline $\begin{array}{l}\text { - CCB + } \beta \text {-Blocker } \\
\text { (Amlodipine+Bisoprolol) }\end{array}$ & 1 & $1,2 \%$ \\
\hline $\begin{array}{l}\text { - } \text { CCB + ARB } \\
\text { (Amlodipine+Valsartan) }\end{array}$ & 1 & $1,2 \%$ \\
\hline 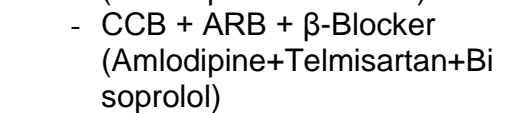 & 2 & $2,4 \%$ \\
\hline $\begin{array}{l}\text { (Amlodipine+Candesartan+B } \\
\text { isoprolol) }\end{array}$ & 1 & $1,2 \%$ \\
\hline
\end{tabular}

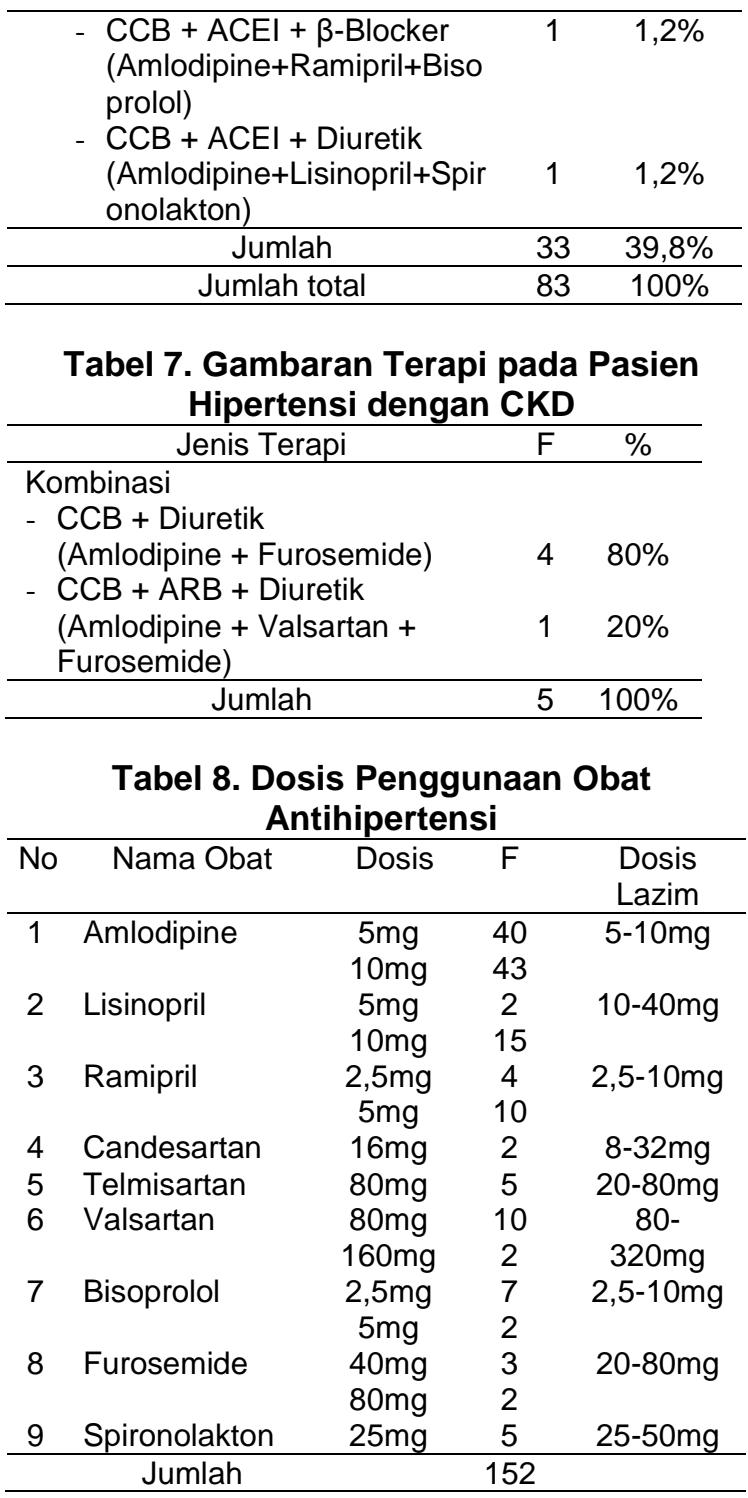

Tabel 9. Kesesuaian Dosis Obat Antihipertensi

\begin{tabular}{ccc}
\hline Kesesuaian & $\mathrm{F}$ & $\%$ \\
\hline Tepat Dosis & 150 & $98,7 \%$ \\
Tidak Tepat Dosis & 2 & $1,3 \%$ \\
\hline Jumlah & 152 & $100 \%$ \\
\hline
\end{tabular}

\section{PEMBAHASAN}

Tabel 1 menunjukkan angka kejadian hipertensi pada perempuan lebih besar dibanding dengan laki-laki. Dari 100 pasien yang ada, sebanyak 75 
pasien $(75 \%)$ terjadi pada perempuan dan pada laki-laki sebanyak 25 pasien (25\%). Hal ini disebabkan adanya faktor-faktor yang dapat meningkatkan tekanan darah yaitu stres dan menopause. Secara psikologis perempuan lebih rentan terhadap stres dibanding laki-laki. Stres dapat meningkatkan hormon adrenalin dan noradrenalin, sehingga pembuluh darah akan menyempit dan selanjutnya akan terjadi kenaikan tekanan darah ${ }^{20}$.

Perempuan lebih banyak menderita penyakit kardiovaskular setelah menopause, sedangkan perempuan yang belum menopause dilindungi oleh hormon estrogen yang berperan dalam meningkatkan kadar High Density Lipoprotein (HDL). Hal ini berhubungan dengan berkurangnya hormon estrogen setelah menopause. Saat menopause perempuan mulai kehilangan sedikit demi sedikit hormon estrogen yang selama ini melindungi pembuluh darah dari kerusakan. Akibatnya, pembuluh darah arterial menjadi kaku, serta merusak lapisan sel dinding pembuluh darah (endotel). Keadaan itu dapat memicu terjadinya pembentukan plak dan mengaktivasi sistem tubuh yang dapat meningkatkan tekanan darah ${ }^{6}$.

Tabel 2 menunjukkan bahwa kategori pasien hipertensi terbanyak berada pada rentang usia Lansia akhir (56-65 thn) yaitu sebanyak 39\%. Hal ini disebabkan karena lansia biasanya mengalami peningkatan tekanan darah sistolik yang berhubungan dengan elastisitas pembuluh darah yang menurun dan meningkatkan risiko terjadinya penyakit yang berhubungan dengan hipertensi ${ }^{15}$. Selain itu, perubahan struktural dan fungsional pada sistem pembuluh perifer bertanggung jawab pada perubahan tekanan darah yang terjadi pada usia lanjut. Perubahan tersebut meliputi aterosklerosis, hilangnya elastisitas jaringan ikat dan penurunan dalam relaksasi otot polos pembuluh darah. Akibatnya, aorta dan arteri besar berkurang kemampuannya dalam mengakomodasi volume darah yang dipompa oleh jantung, sehingga mengakibatkan penurunan curah jantung dan peningkatan tahanan perifer.
Tabel 3 menunjukkan kategori hipertensi terbanyak terdapat pada kategori pasien hipertensi disertai dengan penyakit diabetes melitus (DM) sebanyak 83 pasien. Hipertensi dan diabetes adalah kondisi yang umum terjadi di masyarakat dan merupakan faktor risiko penting penyakit kardiovaskular. Hipertensi lebih sering terjadi pada populasi diabetes dibandingkan populasi non-diabetes. Lebih dari 75 pasien diabetes mempunyai tekanan darah lebih dari 130/80 atau mengkonsumsi obatobatan antihipertensi ${ }^{17}$.

Hipertensi dapat terjadi bersamaan (komorbid) dengan diabetes atau merupakan akibat proses patologis diabetes. Patogenesis hipertensi pada diabetes merupakan proses yang kompleks dan belum sepenuhnya dapat dijelaskan. Disfungsi otonom, aktivasi sistem Renin-AngiotensinAldosterone (RAAS), aktivasi saraf simpatis, resistensi insulin, disfungsi endotel dan kekakuan pembuluh darah arteri merupakan sebagian faktor yang dapat berkontribusi pada terjadinya hipertensi pada diabetes ${ }^{12}$.

Tabel 4 menunjukkan penggunaan terapi antihipertensi tunggal lebih banyak daripada penggunaan terapi kombinasi, yaitu sebanyak $56 \%$. Penggunaan obat antihipertensi dapat berupa obat tunggal maupun obat kombinasi, terapi dengan satu jenis obat antihipertensi atau dengan kombinasi tergantung pada tekanan darah awal dan ada tidaknya komplikasi. Jika terapi dimulai dengan satu jenis obat dan dalam dosis rendah, namun tekanan darah target belum tercapai, maka langkah selanjutnya adalah meningkatkan dosis obat tersebut atau berpindah ke antihipertensi lain dengan dosis rendah. Efek samping biasanya bisa dihindari dengan menggunakan dosis rendah, baik tunggal maupun kombinasi.

Menurut JNC VIII, terapi tunggal dapat diberikan sebagai terapi inisial untuk hipertensi stadium 1 dengan faktor risiko total kardiovaskular rendah atau moderat/sedang, dimulai dengan dosis awal kemudian dapat dinaikkan sampai dosis maksimal jika target tekanan darah belum tercapai. Selanjutnya jika target tekanan darah 
belum juga tercapai dapat diganti dengan obat yang mempunyai mekanisme kerja berbeda, dimulai dengan dosis rendah kemudian dosis dinaikkan sampai dosis maksimal. Bila masih belum tercapai target yang diinginkan dapat ditambah 2 sampai 3 macam obat. Terapi kombinasi 2 obat dosis rendah diberikan untuk terapi inisial pada hipertensi stadium 2 dengan faktor risiko tinggi atau sangat tinggi, bila dengan 2 macam obat target tekanan tidak tercapai dapat diberikan 3 macam obat antihipertensi.

Tabel 5 menunjukkan bahwa penggunaan terapi hipertensi tunggal maupun kombinasi berada di persentasi nilai yang sama, yaitu 50\% : 50\%. Selain itu, golongan obat yang paling banyak digunakan adalah golongan obat CCB (amlodipine) sebanyak 33,3\% dan selanjutnya adalah golongan ARB (valsartan) sebanyak 16,7\%. Pada terapi kombinasi 2 obat, yang lebih banyak digunakan adalah kombinasi antara CCB dengan ACEI sebanyak 16,7\%, sisanya merupakan kombinasi antara CCB dengan ARB, CCB dengan $\beta$-blocker dan CCB dengan diuretik masing-masing sebanyak $8,3 \%$. Sedangkan terapi dengan 3 kombinasi obat, menggunakan golongan obat CCB, ACEI dengan $\beta$-blocker sebanyak $8,3 \%$.

Menurut JNC VIII, terapi lini pertama untuk pengobatan hipertensi dapat menggunakan obat golongan diureik thiazide atau ACEI atau ARB atau CCB. Amlodipin merupakan golongan dihidropiridin yang bersifat vaskulo selektif. Sifat ini menguntungkan karena efeknya langsung pada nodus AV dan SA minimal, menurunkan resistensi perifer tanpa penurunan fungsi jantung yang berarti dan relatif aman dalam kombinasi dengan $\beta$-blocker. Terapi tunggal untuk obat golongan CCB berperan dalam bekerja dengan menghambat masuknya kalsium ke dalam otot polos pembuluh darah sehingga darah mengurangi tahanan perifer ${ }^{11}$.

Berdasarkan Tabel 6, dapat diketahui bahwa jenis terapi pada pasien hipertensi dengan DM lebih banyak menggunakan terapi tunggal dibanding dengan terapi kombinasi, yaitu sebanyak $60,2 \%$. Pada terapi tunggal, golongan obat yang paling banyak digunakan adalah golongan obat CCB (amlodipine) sebanyak $43,4 \%$, diikuti dengan golongan ARB (candesartan, valsartan dan telmisartan) sebanyak $10,8 \%$ dan golongan obat ACEI (ramipril) sebanyak $6 \%$. Pada terapi kombinasi dengan 2 golongan obat yang paling banyak digunakan adalah golongan CCB dengan ACEI sebanyak 25,3\%. Sedangkan pada terapi dengan kombinasi 3 golongan obat, yang lebih banyak digunakan adalah kombinasi CCB, ARB dengan $\beta$-blocker yaitu sebanyak $2,4 \%$.

Golongan obat yang paling banyak digunakan adalah golongan CCB (amlodipine) sebesar $43,4 \%$. Amlodipine bekerja dengan cara menghambat kanal kalsium pada sel otot polos dan jantung. Pemilihan amlodipine ini dikarenakan amlodipine memiliki potensi efek samping yang lebih ringan daripada obat golongan lain seperti golongan ACEI yang dapat menimbulkan efek samping batuk kering dan penurunan fungsi ginjal secara akut, serta hiperkalemia.

Pada penggunaan terapi kombinasi yang paling banyak digunakan adalah antara golongan CCB dengan ACEI yaitu sebesar 25,3\%. Kombinasi CCB dan ACEI menghasilkan pengontrolan tekanan darah yang efektif karena menggunakan dua mekanisme kerja yang berbeda yang saling melengkapi. CCB menurunkan tekanan darah melalui vasodilatasi perifer, juga secara stimulan mengaktifkan Sympathetic Nervous System (SNS) melalui peningkatan aktivitas renin dan produksi angiotensin II. Hal ini akan mempengaruhi efektifitas dari penurunan tekanan darah oleh $\mathrm{CCB}^{16}$. Pada berbagai penelitian klinik diketahui bahwa CCB maupun ACEI memiliki efek positif pada outcome kardiovaskuler, sehingga kombinasi ACEI dan CCB adalah rasional dan memiliki efektiftas yang tinggi. Efek samping CCB yang paling sering ditemui adalah edema perifer. Efek ini terjadi karena dilatasi arteriolar lebih besar daripada sirkulasi vena yang mengakibatkan peningkatan transkapiler gradient dan kebocoran kapiler. Penambahan 
ACEI dapat mengurangi efek ini karena ACEI menyebabkan dilatasi baik pada arteri maupun vena, sehingga tekanan transkapiler kembali normal. Hal ini menyebabkan penurunan edema perifer yang disebabkan oleh $\mathrm{CCB}^{11}$.

Kesesuaian penggunaan obat antihipertensi pada pasien hipertensi dengan penyakit penyerta diabetes mellitus di RS " $X$ " sebesar $95,2 \%$. Hal ini sesuai dengan rekomendasi dari JNC VIII, dimana untuk terapi tunggal dapat menggunakan ARB, ACEI, CCB atau dengan diuretik thiazide. Kemudian dalam pemilihan terapi kombinasi menggunakan golongan obat dengan mekanisme kerja yang berbeda untuk meningkatkan efikasi. Hanya saja, JNC VIII merekomendasikan golongan diuretik thiazide sedangkan di RS " $X$ " menggunakan diuretik hemat kalium yaitu spironolakton dalam penggunaan terapi kombinasi.

Berdasarkan Tabel 7, dapat diketahui bahwa gambaran terapi hipertensi dengan penyakit penyerta CKD adalah dengan menggunakan terapi kombinasi. Terapi dengan kombinasi 2 golongan obat yang paling banyak digunakan adalah golongan obat CCB dengan diuretik yaitu sebanyak $80 \%$, sedangkan sisanya yaitu sebanyak $20 \%$ menggunakan 3 kombinasi golongan obat berupa obat CCB, ARB dengan diuretik. Obat diuretik yang digunakan adalah furosemide. Furosemide merupakan antihipertensi golongan Loopdiuretic. Diuretik merupakan drug of choice bagi penyakit hipertensi disertai gagal ginjal. Diuretik loop merupakan pilihan diuretik yang digunakan pada pasien gagal ginjal karena dapat meningkatkan pengeluaran sodium hingga $20 \%$ dan karena efikasinya tidak bergantung pada Glomelural Filtration Rate (GFR). Selain itu efek samping yang muncul pada penggunaan furosemide jarang ditemui ${ }^{5}$.

Berdasarkan rekomendasi JNC VIII, terapi lini pertama antihipertensi untuk pasien CKD adalah obat golongan ARB atau ACEI, yang dikombinasikan dengan obat golongan lain. ACEI dan ARB mempunyai efek melindungi ginjal (renoprotektif) dalam penyakit ginjal diabetes dan non-diabetes. Salah satu dari kedua obat ini harus digunakan sebagai terapi lini pertama untuk mengontrol tekanan darah dan memelihara fungsi ginjal pada pasienpasien dengan penyakit ginjal $\mathrm{kronis}^{3}$.

Pada pasien yang menggunakan kombinasi obat golongan ARB, CCB dan diuretik sudah sesuai, sedangkan kombinasi antara CCB dengan diuretic dengan persentasi sebesar $80 \%$ adalah tidak tepat karena tidak sesuai dengan rekomendasi dari JNC VIII.

Berdasarkan Tabel 8, ketidaksesuaian dosis yang terjadi adalah adanya kurang dosis (underdose) sebanyak 1,3\%. Dosis yang dianjurkan pada penggunaan obat lisinopril adalah 10-40 mg per hari. Sedangkan pada kasus di atas penggunaan dosis lisinopril adalah $5 \mathrm{mg}$. Kasus tersebut terjadi pada 2 pasien hipertensi dengan DM. Kedua pasien menggunakan lisinopril $5 \mathrm{mg}$ dikombinasikan dengan amlodipine $10 \mathrm{mg}$. Mungkin saja pertimbangan dalam pemilihan dosis ini karena mengacu pada rekomendasi dari JNC VIII dimana penggunaan kombinasi obat dimulai dengan dosis terendah dan selanjutnya dilakukan titrasi dosis jika tujuan tekanan darah tidak tercapai.

\section{SIMPULAN}

Berdasarkan pembahasan pada penjelasan di atas dapat diambil kesimpulan sebagai berikut: Karakteristik pasien hipertensi pada perempuan lebih besar yaitu $75 \%$. Kategori usia pasien hipertensi yang paling besar berada pada kategori lansia akhir (56-65 tahun) sebanyak $39 \%$ dan kategori pasien hipertensi terbanyak adalah pasien hipertensi dengan penyakit penyerta diabetes melitus sebanyak $83 \%$.

Gambaran terapi antihipertensi terbanyak adalah amlodipine untuk terapi tunggal dan untuk terapi kombinasi adalah amlodipine dengan lisinopril.

Pada evaluasi kesesuaian obat dan dosis antihipertensi terdapat ketidaksesuaian penggunaan obat, yaitu 5 kasus pada pasiem hipertensi dengan DM sebesar 4,8\%, 4 kasus pada pasien hipertensi dengan CKD sebesar 
$80 \%$ serta 2 kasus ketidaksesuaian dosis berupa dosis yang kurang dari dosis yang dianjurkan yaitu pada penggunaan obat lisinopril sebesar $1,3 \%$.

\section{SARAN}

Berdasarkan hasil penelitian maka saran peneliti adalah perlu dilakukan penelitian lebih lanjut dengan pengoptimalan evaluasi secara keseluruhan dengan wawancara kepada pasien, dokter dan farmasis untuk menggali informasi lebih dalam mengenai pengobatan yang diberikan kepada pasien.

\section{DAFTAR PUSTAKA}

1. Arikunto, S. Prosedur Penelitian Suatu Pendekatan Praktik. Jakarta: PT Rineka Cipta; 2015

2. Cipolle R.J., Strand L.M. and Morley P.C. Pharmaceutical Care Practice: The PatientCentered Approach to Medication Management, 3rd ed : New York. McGrawHill Education; 2012

3. Depkes RI. Pharmaceutical Care untuk Penyakit Hipertensi. Jakarta: Direktorat Bina Farmasi Komunitas dan Klinik; 2006

4. Dinas Kesehatan, Profil Kesehatan Provinsi Jawa Barat. Bandung: Dinkes Jabar; 2016

5. Dussol B, et al. A Pilot Study Comparing Furosemide and Hydrochlortiazide in Patients with Clinical Hypertension : INC The American Society of Hypertension; 2012

6. Johanna, M.G., Do, H.T.P., Mai, B.L., Frans, J.K., Feskens, J.M. National Prevalence and Associated Risk Factorsof Hypertension and Prehypertension Among Vietnamese Adult. American Journal of Hypertension. 2014

7. Kementrian Kesehatan R1. Modul Penggunaan Obat Rasional. Jakarta: Kemenkes Rl; 2011

8. Kementrian Kesehatan RI. Riset Kesehatan Dasar. Riskesdas Kemenkes Rl; 2013.
9. Messerli FH. Vasodilatory edema: a common side effect of antihypertensive therapy. Am J Hypertens ; 2001;14:978-9.

10.MMN. Basic Pharmacology and Drug Notes: Makasar: Medical Mini Notes; 2017

11.Nafrialdi. Antihipertensi. Sulistia Gan Gunawan (ed). Farmakologi dan Terapi Edisi 5 : Jakarta. Balai Penerbit FKUI ; 2009

12. Nugroho, Edwin. Target Tekanan Darah pada Diabetes Mellitus. Eagle Head Medical Center Surabaya : CDK-222/ 2014 vol.41 no. 11

13. Oparil, S., Zaman, MA., Calhoun, DA. 2003. Pathogenesis of Hypertension, Ann Intern Med 2003.

14. PERKI. Pedoman Tatalaksana Hipertensi Pada Penyakit Kardiovaskular Edisi Pertama. Jakarta: PERKI; 2015

15. Potter, A \& Perry, A.G. Buku Ajar Fundamental Keperawatan: Konsep, Proses dan Praktik Edisi 4 Vol 1. Jakarta: EGC; 2010

16. Quan A, et al. A review of the efficacy of fixed-dose combinations of olmesartan medoxomil/hydrochlorothiazide and amlodipine besylate/benazepril in factorial design studies. Am J Cardiovasc Drugs 2006;6:103-113.

17. Soemantri, D., Sukmana M. Hipertensi pada Diabetes Melitus. Dalam Hipertensi: Manajemen Komprehensif Seri Buku IImiah Kardiologi SMF Kardiologi dan Kedokteran Vaskular. Universitas Airlangga-RSUD Dr Soetomo p.75-88.

18. Sugiyono. Metode Penelitian Kuantitatif Kualitatif dan R\&D. Bandung: Alfabeta ; 2012

19. Suyono \& Lyswanti, E.N.. Studi Penggunaan Obat Antihipertensi Pada Penderita Hipertensi Rawat Inap: Penelitian di RSU Dr. Saiful Anwar, Malang;2008 
20. Tjokroprawiro, et al., Buku Ajar IImu Penyakit Dalam. Surabaya: Air lanngga University Press; 2007

21. WHO. Global Health Estimates: Deaths by Cause, Age, and Sex 2000- 2012. Switzerland; 2012

22. WHO. Global Hypertension Report 2014. http://www.who.int//fs317/en. [23 Maret 2019]; 2014 